\title{
A MODEL OF SPANISH-PORTUGUESE URBAN GROWTH: THE ATLANTIC AXIS
}

\author{
Rubén C. Lois-González \\ Universidad de Santiago de Compostela, (Spain) \\ e-mail: xerulois@vsc.es
}

\begin{abstract}
The Portuguese and the Spanish urban systems have developed with their backs to each other as the result of the different historical development of the two nation-states of the Iberian Peninsula. Since 1986, the date of Spain and Portugal's integration into the European Community, both countries have witnessed the blurring of their common border and the subsequent appearance and consolidation of several Spanish-Portuguese axes of urban development. The most important of them all: the Atlantic Axis (A Coruña-Vigo-Porto) will be the subject matter of this paper.
\end{abstract}

Key words: Urban axis, urban agglomeration, Iberian Peninsula, transnational, coastalization

The process of European integration has been tinged with a series of positive connotations in both Spain and Portugal (the two nation-states of the Iberian Peninsula): the improvement in the levels of social welfare, economic growth and the strengthening of the contacts with the neighbouring country as a consequence of the gradual blurring of the frontiers. As far as this last issue is concerned, it should also be noted that two political unities which had built a strong identity and a highly individualized urban system of their own have managed to recover since 1986 (the date of their integration in the European Community) the understanding and the relations with the neighbouring country. In economic and human terms this has resulted in an increase in the number of exchanges and contacts of all sorts as well as in the search for complementary elements between cities and urban areas on both sides of the border.

\section{THE HISTORIC CONSTRUCTION OF THE SPANISH AND PORTUGUESE URBAN SYSTEMS.}

On several occasions, historians, geographers as well as experts on Politology on the Iberian Peninsula have made manifold references to the fact that Spain and Portugal were 
growing apart. However, this could be regarded as a very recent phenomenon dating back, to be exact, to the $19^{\text {th }}$ century when the frontiers as well as a basic cartography of them were definitely established or even to the $20^{\text {th }}$ century, when the dictatorships of both Franco and Salazar militarised the demarcation of both national territories and encouraged the mistrust of the "neighbour" (López Trigal, Lois \& Guichard, 1997; López Trigal \& Guichard, 2000; Guichard, López Trigal \& Marrou, 2000). Spain and Portugal have adopted clearly different dynamics in a very important aspect, namely, in the construction of two urban systems which have literally turned their backs on each other. This, however, is logical taking into account that the industrialization and urbanization processes taking place in both territories coincided precisely with the period in which the frontier was most impenetrable. In fact there has been a wide consensus in the bibliography on the characterization of the Spanish and Portuguese urban systems. The basis for the organization of the Spanish space was the hegemony of the cities as both the general works and the territorial diagnoses which the Public Administrations elaborated prior to the planning itself (like in the Master Plan for Infrastructures (PDI) or in the roads programme) have made clear (Méndez \& Molinero, 1993; MOPT, 1993). As far as Portugal is concerned, our description of the urban system will be based on the contributions of three influential geographers, J. Gaspar, J. Ferrao (and his typology of the different ways on which the Lusitanian territory has organised) and C.A. Medeiros (an expert on the publication of geographies of Portugal) (Gaspar, 1985; Medeiros, 1987; Ferrao, 2002).

Throughout the $19^{\text {th }}$ century and in the first half of the $20^{\text {th }}$ century, the economic growth in Spain pivoted around certain coastal regions, which from the start comprised several cities and urban agglomerations of certain importance. Examples can be found in $\mathrm{Ca}-$ talonia, the Basque Country, Valencia, the axis Seville-Cádiz, Vigo, A Coruña, GijónOviedo, etc. In the Spanish interior, however, only Madrid stood out in the middle of a series of rural regions with a low population density. Although the Spanish urban system has proved to be much more complex in the last decades, it can still be said that the whole coast could be defined as a group of more or less continuous highly urbanized axes (Carreras \& Nadal, 1990). The best examples can be found firstly on the Mediterranean coast, with a sequence of cities, metropolises and other urban spaces that go all the way from Malaga up to Barcelona and the French border; secondly, in the Basque Country with the continuity Bilbao-San Sebastián; thirdly in the Asturian triangle Gijón-Oviedo and Avilés, also in A Coruña-Santiago-Vigo and finally in Cádiz-Seville. In the interior, apart from Madrid, Zaragoza and the Ebro Valley have grown significantly and so have ValladolidBurgos thereby forming a triangle of urbanization within a huge but not densely populated space with a weak urban network (Méndez, Molinero, 1993) (Fig 1).

Significantly enough, one of the big urban centres or main axes that have emerged in $20^{\text {th }}$-century Spain have developed in the vicinity of Portugal. Only Vigo could be regarded as an example of quite a big city near the border (more than 250,000 inhabitants since the 1970s) and the same could be said of Badajoz or Huelva (around 100,000 inhabitants, in those dates), but these two were far more modest examples (López Trigal, Guichard, 2000). 
Figure 1: Spanish urban system.

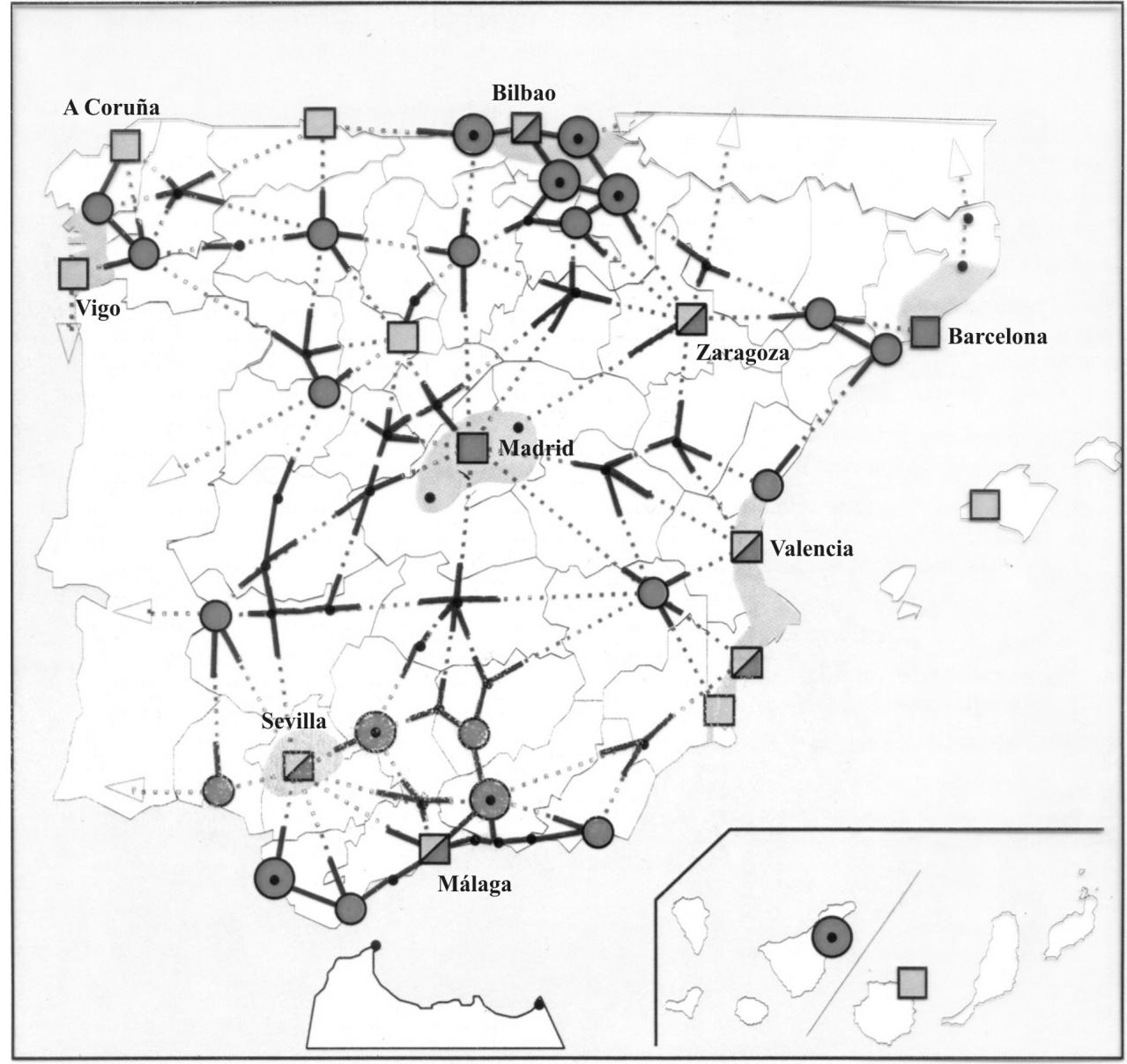

BASIC SYSTEM OF CITIES IN THE HORIZON OF THE PLAN

Urban regions

International Metropolitan Areas

7 National Metropolitan Areas

Regional Metropolitan Areas

- Main urban areas in development

Urban areas of high place potencial

- System of reequilibrium in the horizon of the plan

- .... Fundamental relations 
As it is logical, the models of urban growth in Portugal have been more simple than in Spain. From the $18^{\text {th }}$ century onwards, two main cities, Lisbon in the south and Porto in the north, have been singled out amongst all the other urban centres. In fact some classic geographers attempted to oppose a northern and a southern Portugal, when in fact they were actually speaking about two territorial systems which were centralized by autonomous urban networks. Thus, in the northern region we have Porto and its metropolitan area (with Gaia, Maia, Gondomar and so on) whose population has almost reached the million people for decades, then we have the neighbouring cities of Braga and Guimaraes (between 50,000 and 100,000 inhabitants), further north we have Viana do Castelo and further inland we have the more modest Chaves, Vila Real and Bragança (10,000-15,000 inhabitants). In the south we have Lisbon and its large metropolitan area (2.5 million inhabitants) with its quick connection with medium-sized towns such as Évora, Beja or Santarem. Right in the middle of the country only Aveiro and Coimbra (from 60,000 to 120,000 inhabitants) acted as links between these well-defined sub-systems (Barata Salgueiro, 1992; Ferrao, 2002).

We have just referred to the opposition north-south in Portugal yet a lot more signifycant is the contrast that exists between the coastal and inland areas. Both Lisbon and Porto are coastal cities and harbours and their metropolitan areas are organised according to their distance from the Atlantic. Braga, Guimaraes, Coimbra or Aveiro are also located along the coast and significantly enough there are no inland urban centres that reach the 50,000 inhabitants. Therefore it could be safely concluded that the Portuguese urban system shows signs of a process of coastalisation which has even increased in recent times (Barata Salgueiro, 1992; Ferrao, 2002) (Figure 2). The economy as well as the axes of urban growth in Portugal look towards the Atlantic and once more they have placed themselves turning their backs on Spain.

All we have said so far has given ample proof that the Spanish and Portuguese urban systems were constructed in a completely different way. The decades of the 1960s and the 1970s, precisely the final stage of both Franco's and Salazar's dictatorships, a time when crossing the border implied overcoming many obstacles, were the period of the biggest economic development and demographic growth in the cities. Nevertheless, there are a couple of exceptions to this general rule of separated urban growth. In the south the location of the main towns in Algarve (Faro, Vila-Real de Santo António, etc.) and in the western end of Andalusia along the coast (Ayamonte, Huelva, etc.) contributed to movements of population and they also fostered and maintained the economic exchange between those communities (Jurado, 2001). A similar phenomenon could be witnessed in Badajoz and Elvas, two towns which are no more than $20 \mathrm{~km}$ away from each other and which maintained fluid contacts despite the fact that the Spanish-Portuguese contacts in the inland areas of the Iberian Peninsula had been traditionally weak (Campesino, 2000; Alonso, Caetano, 2002).

The area of Minho, between Galicia and Northern Portugal, or even better between Vigo and Porto, was, without any doubt, the area where the number of people and the volume of goods crossing the border was bigger, even, against all expectations, during Franco's and Salazar's dictatorships. This phenomenon has a straightforward explanation. First of all, we are speaking of a wealthy and densely populated area. Secondly, the language which is spo-ken on both sides of the border (Galician, nowadays the co-official language 
of Galicia and Portuguese) is practically the same language. Finally, the fact that a big city like Vigo is only $25 \mathrm{~km}$ away from Portugal together with the existence of an important group of small chief urban centres on the Portuguese side of the border like Valença, Monçao, Caminha, Vila Nova da Cerveira, etc. enhanced the neighbouring contacts. As a result, thousands of Galician people crossed the border everyday to buy in Portugal whereas the fact that certain food and tools were more readily available in the area of Vigo gave rise to a similar flow of Portuguese people in the opposite direction (Lois, 1997).

Figure 2: Portuguese urban population.

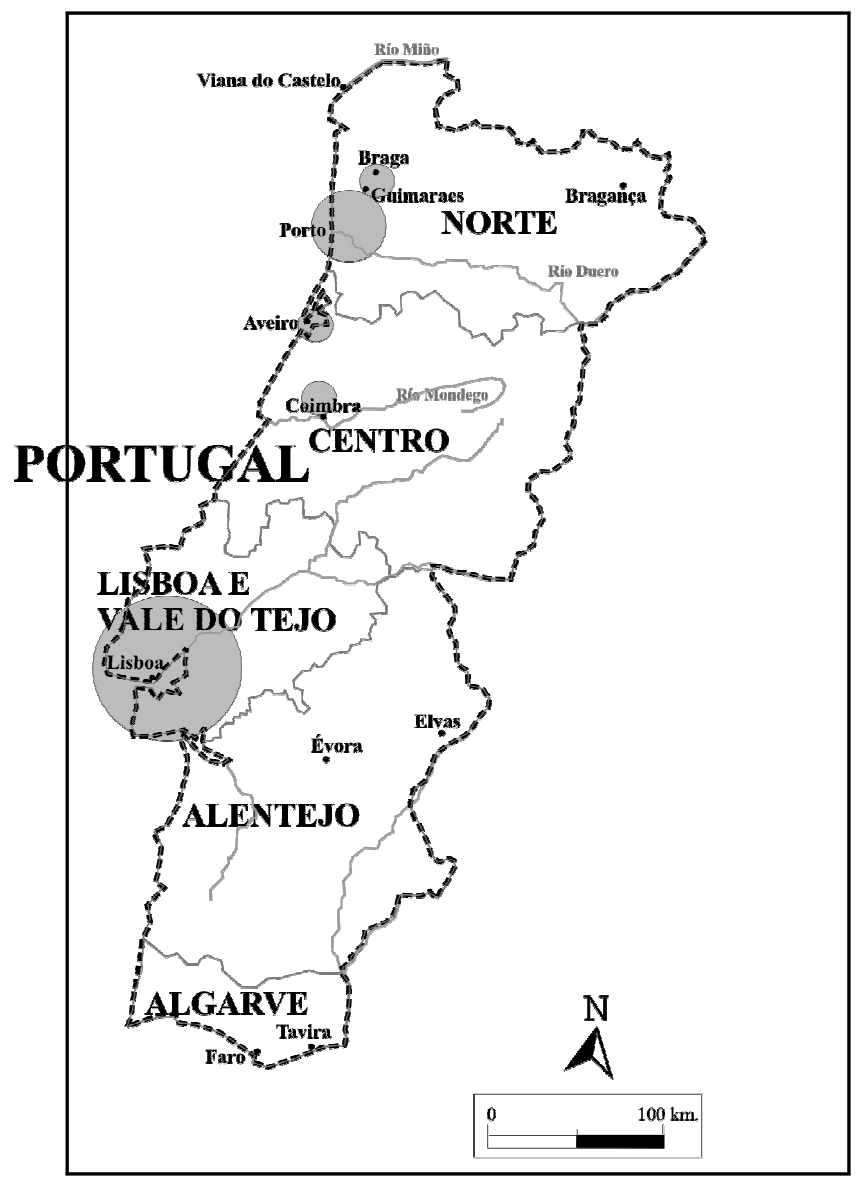

\section{THE CONCEPT OF “URBAN AXIS” AND ITS APPLICATION TO THE IBERIAN PENINSULA}

The interpretations some experts have given about the Portuguese and Spanish urban systems seem to agree in one key aspect. If until the 1980s the city, understood the latter as a 
perfectly individualized urban centre, was taken as the basic reference for the study of the urban system, from that date onwards the leading role has been given to the urban agglomerations (aglomeraciones urbanas), the urban regions (regiones urbanas), the metropolitan areas (áreas metropolitanas) and the axes of geospatial development (ejes de crecimiento geoespacial). A urban agglomeration is a relatively big area made up of a pivotal city and its outskirts with which it is linked and integrated in functional terms but also as far as the everyday movement of population is concerned (Zoido, De la Vega, Morales, Mas \& Lois, 2000). An example of urban agglomeration could be that of Vigo with a central city (around 300,000 inhabitants) surrounded by 15 municipalities. These municipalities amount to 150,000 inhabitants living no more than a thirty-minute drive away from the main nucleus. Something similar can also be seen in Braga or Guimaraes with central cities of 50,000 to 100,000 inhabitants and sprawls between 200,000 and 250,000.

The urban region (región urbana) could be understood in similar terms to those of the urban agglomeration but at a larger scale. In the Iberian Peninsula the term is deployed for Madrid (with a population of 5 million, out of which three million live in the capital of Spain) Barcelona (with five and 1.5 million respectively), Lisbon (2.5 million in its area), and with more reservations for Porto and the coastline of the Basque Country (Zoido, De la Vega, Morales, Mas \& Lois, 2000). Some of these spaces have also been labelled as metropolitan areas or regions, however this expression tends to be used whenever the cooperation at a supramunicipal level has been officially acknowledged (Zoido, De la Vega, Morales, Mas \& Lois, 2000). This happens in the administrative entities which form the metropolitan areas of Porto and Lisbon, however in Spain this concept, which has been so highly vindicated by experts, has not provided so far a meaningful example that shows it can work effectively. Nevertheless, the very existence of an Autonomous Community of Madrid, which coincides to a certain extent with its urban region could be regarded as an effective substitute.

Against these deeply-rooted concepts that have been traditionally deployed for the analysis of the urban system, there has been a move especially in the Spanish bibliography towards the study and characterization of the so-called urban axes. An axis is a relatively large space, connected by a high capacity communication route such as a motorway or a high-speed rail, where the population and the economic activity are gathered, which makes the most of both a pre-existing urban network as well as of the considerable improvement in the conditions of accessibility in the area. An axis is a complex space with a proliferation of cities and urban centres of different sizes (Méndez, 1996; Alonso-Logroño, 1996). In Portugal the concept of axis is mainly used to insist on the improvement that has taken place in the connections between Porto-Lisbon. Several wide axes of development can be found in Spain: one of them along the Mediterranean coast, another all along the Ebro river, and finally another one between the Basque Country and Catalonia.

Amongst those Iberian authors responsible for the concept as well as for the research about the existence of axes of growth but also about the new ways of urbanization, several names should be cited. R. Méndez and I. Caravaca have repeatedly applied the concept of axis to their studies on the organization of space and the new economy that emerged in 
Spain in the 1980s (Méndez \& Caravaca, 1996). The Portuguese J. Ferrao has attempted on several occasions to characterize his country by insisting on the replacement of the traditional dichotomies north-south and coastal-inland areas by an articulation around urban agglomerations, arquipelagos where not only the population, but also the economic potentials and the centres of power usually gather (Ferrao, 2002). J.L. Sánchez y P. Alonso, two young researchers, have focused almost entirely on the study of axes. The former has directed his research almost exclusively to axes of big dimensions as emerging centres of development, whereas the former, P. Alonso, is more concerned with the study of the Ebro Corridor (the axis whose centre is Zaragoza) (Sánchez-Hernández, 1996; Alonso-Logroño, 1996).

Although there are other researchers who have tackled in their works the concept and spatial dimension we are referring to this paper aims to present, though briefly, the way the Spanish-Portuguese urban axes have been studied in recent times. On the southern coast, the group of researchers from the Universidad de Huelva supervised by J. Márquez have insisted on the existence of an onubense-algarví axis (which comprises the western part of Andalusia and the Algarve). A strong emphasis is placed on the population continuity all along the sector, that is, on the proliferation of small and medium-sized towns with high demographic densities, on the complementarity of both regions as far as tourism goes and on the constantly increasing transnational movement of persons, capital, trade and services (Márquez, 2000). Nonetheless, if anywhere, the place where the existence of a Spanish-Portuguese urban axis has become more popular has been Galicia and the so-called minhote region of Portugal. In this particular case, almost all the approaches stress the existence of a continuity of cities and urban spaces between Ferrol-A Coruña, in the north, and the metropolitan area of Porto in the south. The discussion that follows is going to revolve around this particular axis, which is more than $250 \mathrm{~km}$ long and 30/40 km wide and holds a population of up to 4 million (Lois, 1997; Meixide \& Castro, 2001).

\section{THE GALICIAN-PORTUGUESE ATLANTIC URBAN AXIS: DEFINING CRITERIA.}

The name Atlantic urban axis was coined in the Spanish region of Galicia back in the 1980s to refer to a space that comprised a third of the total human contingency of the region, an overwhelming majority of the big companies of the territory and five out of the seven most important cities in Galicia (Vigo and A Coruña with 250,000/300,000 inhabitants each of them and 350,000/450,000 if we also add the population of the areas of their direct influence, Santiago, Pontevedra and Ferrol with 80,000/100,000, although their urban agglomerations are between 120,000/150,000 dwellers). Even though the Atlantic urban axis only amounts to $7,000 \mathrm{~km}^{2}$ out of a regional area of $30,000 \mathrm{~km}^{2}$. The rest of the territory was and is still seen as a sort of huge rural periphery undergoing severe problems of depopulation where only the main cities (Lugo and Ourense) and a group of small towns act as industrial poles with a certain degree of dynamism (Lois, 1997). 
Figure 3. Urban Atlantic system.

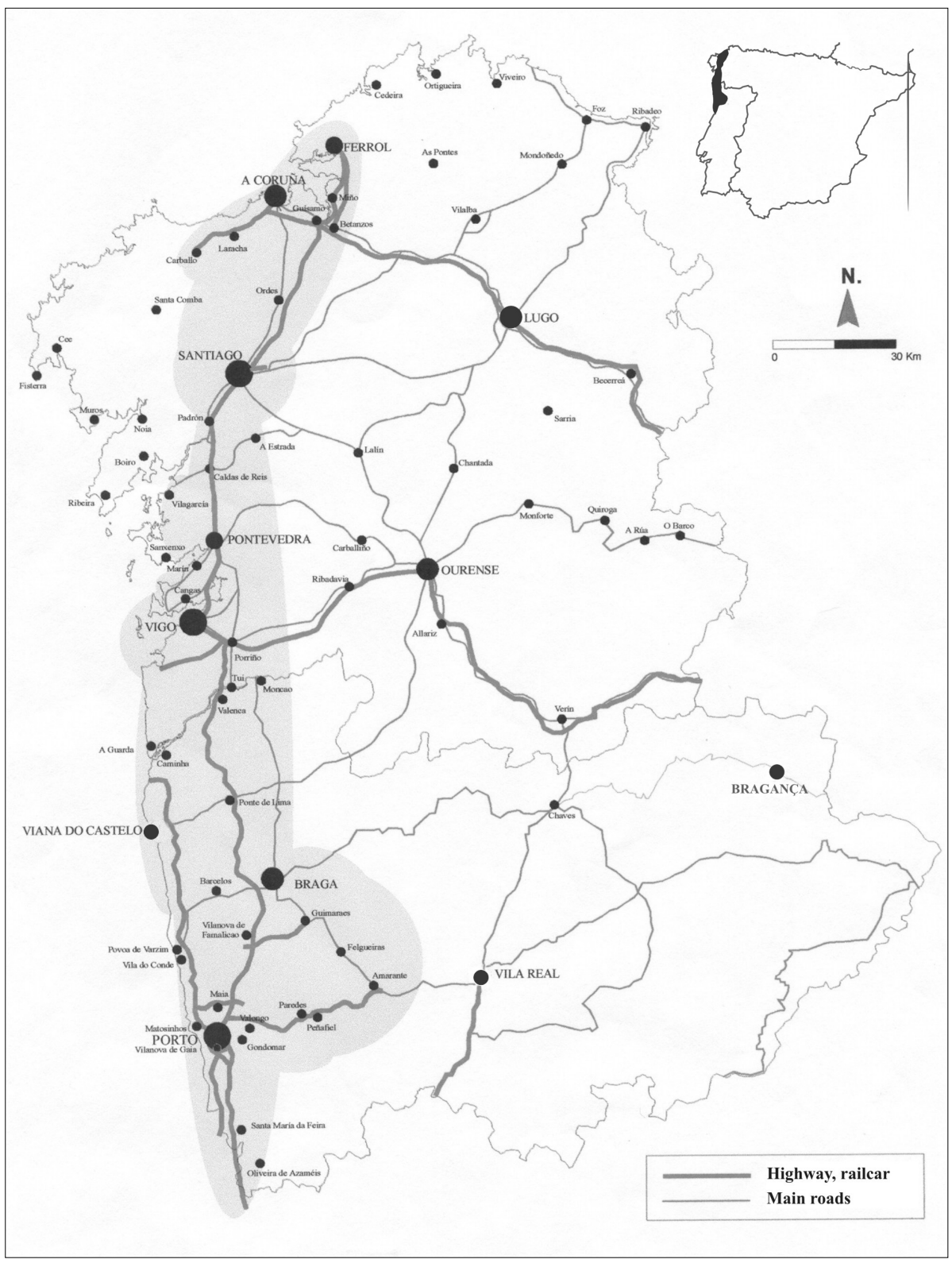

While Galicia was fully involved in a further characterization of the Atlantic urban axis, a similar process of urban concentration along the coastline was also taking place in the neighbouring Portugal. In the Regiao Norte, or Northern region, the economic activity and the human contingent were organised around the Grande Porto (1.2 million inhabitants), the areas of Braga and Guimaraes (with a population of almost 900,000 inhabitants) and to a 
lesser extent around the south part of the metropolitan region of Porto (around 300,000 inhabitants between Douro and Vouga) and around the regions on the border with Galicia (the area Minho-Lima with 250, 000 inhabitants). Once again these figures provide a stark contrast to the high rate of depopulation and the lethargy of the rural inland areas, especially those of the Alto Douro and Tras-Os-Montes (Meixide \& Castro, 2001).

Unlike the general trend followed in the Spanish and Portuguese urban systems, which have developed with their backs to each other, all the north-western region of the Iberian Peninsula (Galicia-Regiao Norte of Portugal) has witnessed the strengthening of a big space of urbanization all along the Atlantic which adopts the shape of a north-south axis. This axis was formed separately in Galicia and in Northern Portugal when there still used to be a border. Therefore, the causes of its creation could be put down to the importance which the human occupation of the space in the coastal areas has had from a historical point of view and to the key role the big harbours of A Coruna, Vigo and Porto had for the urban growth of this area. Strictly speaking, the Atlantic urban axis could be said to stretch from the north of Galicia as far as Lisbon, since the urban continuity and the concentration of the big productive centres of Portugal between Porto and Lisbon goes unquestioned. This notwithstanding, the current paper will only be devoted to the axis Galicia-Regiao Norte and it will insist on the effects the creation of such a transnational space of development has had.

Focusing on the characterization of this Atlantic axis, we will enumerate five of its defining traits which help to reinforce and validate the concept of urban axis of development.

a) As we have already mentioned above, a big number of cities together with their urban agglomerations have been laid out following a longitudinal axis in the Atlantic coastal side of the Iberian Peninsula. Thus, in the north of Galicia, in the Artabran Gulf, we find the cities of A Coruña and Ferrol as well as the highly urbanised area between them both and less than an hour away moving southwards we come across the area of Santiago, which is, once again, a sign of intense urbanisation which goes on further south without any interruption as far as the Rías Baixas, whose pivotal cities are Pontevedra and Vigo. Close to the former, a cluster of towns on the Portuguese side of the border (Valença, Viana do Castelo, etc.) show how near the border one finds the first areas of urbanisation in the Portuguese territory. Only an hour-drive from the border, Braga in the Cávado, and Guimaraes in the Valley of the river Ave could be taken as the prelude to the metropolitan area of Porto, the most outstanding urban example in this huge space. The cities as well as their urban agglomerations follow one another and they are very close mainly because there is a motorway which has made the communication north-south much easier, thereby reinforcing the unity of the Atlantic axis.

b) A consequence of this intense urbanization is the concentration of the human contingent along this longitudinal layout of cities and towns. In the vicinity of Porto, Guimaraes, Braga, Vigo and A Coruña-Ferrol densities over $250 / 300$ inhabitants $/ \mathrm{km}^{2}$ are the rule, whereas the in-between territories in some cases these densities may even rise to over 150 inhabitants $/ \mathrm{km}^{2}$. This big demographic volume (of up to 4 million people) in not a very big area is a factual reality which has been perceived rather as an advantage than as a hindrance by several firms and companies which aim at a binational market. 
c) The axis also acts as an unquestioned location for firms from all over Galicia and from most of Portugal. Thus, we are facing a space with a high rate of industrial employment taking in over $40 \%$ of the employed people in northern Portugal and over $25 \%$ in the Galician stretch of the axis. Both the textile industry with countless workrooms there and the corporation of Zara in A Coruña stand out above all the other industries but so do the timber industry and the furniture factories (in the area of Porto, Pontevedra, Santiago, etc.), as well as all those industries devoted to the exploitation of the marine resources (Vigo is one of the main centres at a European level). Finally the establishment of multinational companies in this area results in the emergence of big automobile plants (the most important in Vigo) or oil refineries (Grande Porto and A Coruña). The whole axis is regarded as a functional, market and labour force recruitment unity by those companies (regardless of their origin) which have decided to strengthen their presence in the Iberian Peninsula.

d) As regards the process of integration Galicia-North of Portugal a very outstanding fact should be noted: the mutual trade has multiplied by ten between 1990 and 2000. Therefore two territories which were relatively far away from each other before their integration into the European Community, have started to create and consolidate a single market in products such as food, automobiles, timber and furniture, linen, etc. This constantly growing exchange has not had however its counterpart in the number of direct investments each country has made on its neighbour. the phenomenon can be explained in most cases if we take into account that from the furthest-lying city on the Atlantic Axis the whole trading process of this huge urbanization space could be supervised without having to purchase any companies in the neighbouring country.

e) The final aspect that stands out in the shaping of the Galician-Portuguese Atlantic axis is the mobility of population. It is reckoned that around 7,000 people cross the border everyday to go to their working place or activity. In most cases, we are talking about gangs of unskilled workers, the staff of health centres who work on some councils on the Portuguese side of the border, and representatives or haulers, all of whom are the protagonists and agents of the boost to the economy we have been discussing so far. However, the flow we are witnessing is still an average one, but it is improving year after year thanks to a series of factors: the setting-up of more Galician companies in northern Portugal, where the industrial land is much cheaper, the purchase of dwelling places in the neighbouring country, etc. Together with the daily mobility, the rate of one-day visits of inhabitants of both spaces (to go shopping, to stroll, etc) has increased considerably. A research which was carried out by the Galician regional Government has found out that there are 3 million one-day visits of Northern Portuguese citizens to Galicia per year. In fact several Portuguese towns such as Valença, Vilanova da Cerveira or Monçao are part of the area of influence of Vigo. Moreover, it is very common for the average Galician or northern-Portuguese citizen to travel to the neighbouring country to spend there part of their spare time.

Although there may be other secondary signs that could serve as indicators of how well this increasingly interconnected urban space on the northern coast of the Iberian Peninsula 
works we consider that the aforementioned five are enough proof of the process of integration which is under way, a process which, as we are going to see, brings forth hopes but also several difficulties of continuity in the future.

\section{STRENGTHS AND WEAKNESSES IN THE PROCESS OF CONSOLIDATION OF THE ATLANTIC URBAN AXIS}

One would think it obvious that the level of cohesion of the Galician-Portuguese Atlantic axis should be maintained, however, whether this level will be increased or whether it will come to a standstill in the future depends on a series of factors which we will try to put forward here as succinctly as possible. On the one hand, the creation of a big crowded urban space in the north-west of the Iberian Peninsula with several million inhabitants has undeniable advantages at the economic level. Besides, the fact that a former periphery (Galicia in relation to other much wealthier areas within the Spanish territory and to a lesser extent Porto as a result of its subordination to Lisbon), has become a powerful space can explain the growing interest the social, political and economic driving forces behind the axis have shown in promoting its economic potentials. However, in practice this general tendency to encourage and foster the integration has several difficulties to overcome. Coordinating large-scale infrastructures, harbours and airports is not one of the easiest to tackle obstacles and neither is the different political and administrative organization of the Portuguese and Spanish territories. Portugal has a highly centralised government, which implies there is a high dependence on Lisbon as far as decision-making goes, whereas in Spain (and consequently in Galicia) there is a rather high the level of self-government.

As we have pointed out, the Atlantic axis in the north-western corner of the Iberian Peninsula has helped to set up an urban economy of agglomeration. The advantages of this economy are manifold. Firstly, the existence of a four-million-consumer market. Secondly, the availability of skilled labour force, ancillary companies which can help others to settle and the presence of practically all the different industrial branches in an intricate sector of cities and their suburban fringes is in the particular case of the Atlantic axis a fact. Thirdly, it should also be argued that the number of inhabitants as well as the activity that has been generated in this area has encouraged the improvement and number of foreign connections (through the four existing airports, two of which are international, or the three big ports located at the entrance of Europe) (Meixide \& Castro, 2001).

As a general rule, the positive effects of the economic agglomeration become obvious at two levels. On the one hand, some multinationals have shown a growing interest in being based on the axis, since the benefits of aiming at a Iberian market (neither Portuguese nor Spanish, but both) are easily perceived. Moreover, the axis can function as a huge intermodal transport node or freight village which can act as an interface between the maritime freight transport and the motorways that connect the harbours with inland Spain and with the rest of Europe. On the other hand, in some productive sectors such as in the textile, the fish processing or the timber industries, have emerged and they have proved to be quite successful in today's highly-competitive globalized economy (Lois, 1997). 
The transnational dimension of the Atlantic axis is accompanied by other more easily seen advantages for the average citizen, which should be translated into its future reinforcement. Thus, the creation of a single market has allowed both Galician and Portuguese workers from the north to have access to two national markets which still retain some of their idiosyncratic traits. The advantages for the commercial distribution which have arisen as a consequence of the creation of the axis have spurred a growing number of firms into expanding their sales area in the neighbouring territory (oil companies, industrial abattoirs, agroalimentary companies etc.), thereby bolstering up the functionality of this binational urban system. This reinforcement has granted and still does grant people the possibility of getting to know the culture of the other country, a culture which, in the particular case of Galicia and Portugal, is very similar because the language has a common origin that dates back to the Middle Ages. Besides, certain similarities can also be traced in some of the folklore traditions of both countries.

However, despite all the elements that seem to lead to a further integration of the urban systems of the littoral Galicia and the Regiao Norte there are some particular difficultties that raise. Amongst them the most important is perhaps the policy concerning largescale communication infrastructures. The EU has recommended the adoption of measures that tend to reinforce even more the complementarity of the Portuguese and Spanish harbours, especially those overlooking the Atlantic. In A Coruña the traffic of bulk carriers (of liquid oil products) does not generate any kind of tensions and disputes with Vigo, which has specialised in containers and products of the automobile and fishing industries. The installations of Leixoes-Porto attract a denser, more complex flow of goods with hydrocarbons and containerization, but that so far has not been the cause of any competitive tensions with Galicia. With an eye on the future, an increase in the maritime traffic in the area will bring forth situations of mistrust if not of rivalry between the harbour authorities of the three cities. This will happen unless instruments of cooperation and joint management of the harbours that belong to the Atlantic axis are provided, a measure which, however, seems to take time to put into practice. An already problematic and highly competitive field is that of the communications by air and thus the direct competitiveness between AlvedroA Coruña, Lavacolla-Santiago, Peinador-Vigo and Sá Carneiro-Porto has been a controversial fact since the 1990 s.

Finally, one of the main obstacles to the future integration of the axis has to do with the institutions that are involved in its management. In the 1990s the Comisión de Trabajo Galicia-Regiao Norte (the Working Commission Galicia-Regiao Norte) as well as the existence of the stable framework of coordination between the different governments of the cities, the so-called Eixo Atlántico has helped to foster the transnational cooperation. Nevertheless, in the coming years it will be necessary to put into practice firstly concepts such as the metropolitan areas (áreas metropolitanas) or the urban areas (áreas urbanas) which should interrelate amongst themselves, secondly dynamics of joint management of the economic interests of the Atlantic axis against those of Brussels, Madrid or Lisbon, and thirdly strategic plans for large-scale communication infrastructures. The huge political and administrative differences between Spain and Portugal inherited from past times hinders the fulfilment of all these needs. The coordination of some Galician councils of scarce power and 
economic resources and the wealthy Portuguese concelhos proves to be a tough if not an impossible task. The same could be said of the attempt to bring together the powerful Autonomous Community of Galicia and a body such as the Comisiao de Coordenaçao da Regiao Norte. These contrasts will certainly slow down the otherwise profitable and advantageous process of integration of the NW Iberian urban axis.

\section{FINAL COMMENTS}

All throughout this paper, we have tried to stress two key ideas which, from our point of view, are extremely important. On the one hand, we have highlighted how useful the concept of urban axis has turned out to be for the analysis of new spatial realities in Europe. This expression, urban axis (eje urbano) has become considerably popular in the geographic research that has been carried out in Spain in the last decades. On the other hand, we have also underlined the emerging interest in the characterization of transnational urban systems within the larger framework of the European Union. By using the example of the Atlantic urban axis it is possible to understand quite a complex urban reality in some peripheral territories which had been hegemonically rural until the $20^{\text {th }}$ century. At the same time it should also be noticed how some urban and spatial dynamics which could already be considered as fully Iberian, start to qualify and question the traditional characterizations and interpretations of the Spanish and Portuguese urban systems as two separate realities.

\section{References}

Alonso Logroño, Ma.P., 1996: Procesos de difusión axial. La industria en Zaragoza, Universidad de Zaragoza, Tesis Doctorales.

Barata Salgueiro, T., 1992: A cidade em Portugal. Uma geografia urbana, Afrontamento, Lisboa.

Carreras, A. and Nadal, J. (Ed.), 1990: Pautas regionales de la industrialización española, Ariel, Barcelona.

Ferrao, J., 2002: "Portugal, três geografias en recombinaçao: espacialidades, mapas cognitivos e identidades territoriais", Lusotopie 10, 2002/2, 151-159.

Gaspar, J., 1985: A dinâmica funcional do centro de Lisboa, Horizonte, Lisboa.

Guichard, F.; López Trigal, L. and Marrou, L., 2000: Itnerarios transfronterizos en la Península Ibérica, Fundación Afonso Henriques, Zamora.

Lois González, R.C., 1997: "El eje urbano alántico, Galicia-Norte de Portugal”, in López Trigal, L.; Lois González, R. and Guichard, F., La articulación territorial de la raya hispano-portuguesa, Fundación Afonso Henriques, Zamora, 137-143.

Lois González, R., 2002: “As relaçons de Portugal com a Ibéria: uma olhada desde a Galiza", Lusotopie 10, 2002/2, 193-211.

López Trigal, L.; Lois González, R. and Guichard, F., 1997: La articulación territorial de la raya hispano-portuguesa, Fundación Afonso Henriques, Zamora. 
López Trigal, L. and Guichard, F., 2000: La frontera hispano-portuguesa. Nuevo espacio de atracción y cooperación, Fundación Afonso Henriques, Zamora.

Márquez Domínguez, J. and Jurado Almonte, J.M., 2000: "Los espacios de repulsión y atracción en la frontera suroccidental hispano-portuguesa", López Trigal, L. and Guichard, F., La frontera hispano-portuguesa. Nuevo espacio de atracción y cooperación, Fundación Afonso Henriques, Zamora, 119-135.

Medeiros, C.A., Introduçao á Geografia de Portugal, Estampa, Lisboa.

Meixide, A. and Castro, A. de (Coord.), 2001: Galicia e a Rexión Norte de Portugal: un espacio económico europeo, Fundación Caixa Galicia, A Coruña.

Méndez, R., 1996: Geografía Económica, Ariel, Barcelona.

Méndez, R. and Caravaca, I., 1998: Organización industrial y territorio, Síntesis, Madrid.

Méndez, R. and Molinero, F, 1993: Geografía de España, Ariel, Barcelona.

MOPT, 1993: Plan Director de Infraestructuras, MOPT, Madrid.

Sánchez Hernández, J.L., 1996, El eje Irún-Aveiro. Geografía de un eje de desarrollo, Caja Duero, Salamanca.

Zoido, F; De la Vega, S.; Morales, G.; Mas, R. and Lois, R., 2000: Diccionario de Geografía urbana, urbanismo y ordenación del territorio, Ariel, Barcelona. 